\title{
Camus: Betrokke buitestaander
}

\begin{abstract}
Book Title:
Die Pes: Uit die Frans vertaal deur Piet de Jager
\end{abstract}

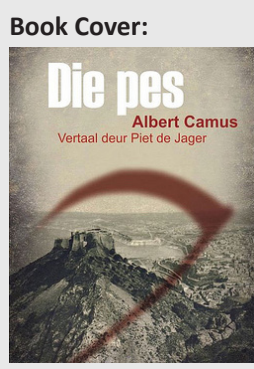

Author:

Albert Camus

ISBN:

978-1-86919-452-9

Publisher:

Protea Boekehuis, Pretoria,

2012, 280 p., ZAR194.00*

*Bookprice at time of review

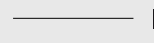

Review Title:

Camus: Betrokke

buitestaander

Reviewer:

A.J. Coetzee ${ }^{1}$

Affiliation:

${ }^{1}$ Department of Afrikaans

and Dutch, University of

Western Cape, South Africa

Email:

ampiec@mweb.co.za

Postal address:

Private Bag X17, Bellville

7535, South Africa

How to cite this book review:

Coetzee, A., 2013, 'Camus:

Betrokke buitestaander',

Literator 34(2), Art. \#388,

2 pages. http://dx.doi.org/

10.4102/lit.v34i2.388

\section{Copyright:}

(C) 2013. The Authors

Licensee: AOSIS

OpenJournals. This work

is licensed under the

Creative Commons

Attribution License.

Read online:
Albert Camus is in 1913 in Mondovi, Algerië (toe Franse Algerië) gebore, en hy sterf in 1960 in 'n motorongeluk in Yonne, Frankryk.

Hy studeer filosofie, word joernalis, redakteur van 'n klandestiene koerant, lid van die Résistance, dramaturg, essayis. Maar uiteindelik het hy bekend geraak deur sy romans: L'Etranger (1942), in Afrikaans vertaal deur Jan Rabie as Die buitestaander (1966); en dan La Peste (1947), La Chute (1956), en verhale soos L'Exil et le royaume (1957). Dan is daar nog ander bekende sosiopolitieke en filosofiese diskoerse soos Le Mythe de Sisyphe (1943) en L'Homme révolté (1951). Laasgenoemde handel oor die aard van opstand: 'n debat tussen hom en Jean-Paul Sartre.

Deur die betrokkenheid van sy prosa met byvoorbeeld armoede, magsmisbruik, die absurde; en in sy politieke en filosofiese essays oor eksistensialisme, kolonialisme, die absurde, Marxisme en die Christelike ideologie, was hy prominent in die denkwêreld van die middel van die twintigste eeu in Europa. Maar Noord-Afrika was sy eintlike milieu. Sy essays, kortverhale en romans soos Die pes en Die buitestaander het 'n sterk verbintenis met Algerië, veral vir die literêre leser. Algerië: ' $n$ land van kontradiksies, van mense en 'n dikwels vyandige natuur. Hier is sy passie vir geregtigheid openbaar, maar sonder die verlies van lewens deur opstand. Hy is 'n rebel, maar met' $n$ weerstand teen geweld.

In Die pes breek daar iewers in die jare veertig van die negentiende eeu 'n pes uit in die Algerynse dorp Oran in Noord-Afrika, in die verre noorde. (Is dit betekenisvol dat dit naby Spanje - Europa - is, eintlik nie te ver van die Straat van Gibraltar nie?) Dit begin met die vrekte van duisende rotte, en dan sterf mense. Mense wil eers nie glo dat dit'n pes is nie; maar wanneer die besef kom, en die dodetal word meer, word die dorp gesluit en onder kwarantyn geplaas. ' $n$ Nuwe serum word ontdek en skynbaar verminder die sterftes, maar die pes wyk nie heeltemal nie.

Die hoofkarakter in die verhaal is dr Bernard Rieux, wat met die hulp van enkele vrywilligers die pes probeer beveg. Rieux is toegewyd aan sy taak, betrokke daarby, maar tog wetenskaplik onbetrokke.

Van 'n narratief is daar nie veel sprake nie, eerder situasies wat beskryf word deur ' $n$ verteller wat skynbaar afwesig is, maar tog ook daar is, want telkens word daar van 'ons' gepraat. Aan die begin word na ' $n$ verteller verwys ' ... wie se identiteit mettertyd bekend gemaak sal word ...' (bl. 11). Hierdie verteller neem waar, teken aan, gebruik dokumente, doen verslag.

Die Pes is al ' $n$ allegorie genoem, waar die werklikheid van die pes simboliese waarde kry. Die karakters is stemme in 'n dialoog: van die Tweede Wêreldoorlog, van 'n konsentrasiekamp waar die pes die vyand is wat oorheers. Maar veral ook ' $n$ debat oor God en lyding. Die aanhaling van Daniel Defoe aan die begin van die boek gee die toon aan:

Om een soort gevangenisstraf deur middel van 'n ander uit te beeld, is net so redelik as om iets wat bestaan uit te beeld deur iets wat nie bestaan nie.

So sou ' $n$ mens die beskrywing van een van die mees tragiese oomblikke - dié van ' $n$ sterwende kind - kan lees as allegories vir die ongevoeligheid van God.

Die priester, Paneloux, en dr. Rieux aanskou die sterwe van die kind:

Maar die kind hou aan skree en die ander siekes begin rusteloos raak. Die pasiënt aan die anderkant van die saal wat van tyd tot tyd sulke lang gille gegee het, versnel die tempo van sy gille totdat dit een ononderbroke kreet is en die ander begin al hoe harder kerm. ' $n$ Vloedgolf snikke spoel deur die saal en Paneloux se gebed verdrink daarin. Rieux klem die bedstyl versuf van uitputting en afsku vas en knyp sy oë toe. (bl. 197)

Dis die eerste keer dat Rieux emosie toon, veral in die kort gesprek met die priester. Die priester sê: 'Ek verstaan ... Sulke dinge maak mens opstandig omdat dit ons verstand te bowe gaan. Maar 
miskien moet ons ook die dinge liefhê wat ons nie verstaan nie.' En Rieux antwoord:

Nee, Vader ... Ek het 'n totaal ander begrip van die liefde. En totdat ek my laaste asem uitblaas, sal ek weier om hierdie skepping waarin kinders gemartel word, lief te hê. (bl. 198)

Hierdie realiteit illustreer vir Camus (en dié argument voer hy verder in L'Homme révolté) dat daar 'n groot gaping is tussen die lyding van die mens en die raadsplan van God en dit lei tot aanvaarding of opstand. En as God regeer, dan is hy verantwoordelik - soos vir die lyding van 'n kind.
Aan die einde van die boek is die verteller - die ' $\mathrm{ek}^{\prime}$ - dr Rieux self, die afwesige verteller, wat homself objektiveer en onbetrokke vertel. Hy kan egter nie altyd afstandelik bly nie.

Dit was nie nodig om Piet de Jager se vertaling te vergelyk met die oorspronklike teks nie. Ek kon dit lees soos die oorspronklike. Ons kan dankie sê dat ons nou die geleentheid het om ook Camus in Afrikaans te lees.

(Sekere feite wat gebruik is in hierdie resensie kom uit Germaine Brée, 1962, Camus. A Collection of Critical Essays, Prentice-Hall Inc., Englewood Cliffs, NJ.) 